\title{
Die invloed van die New Age-beweging op die onderwysagenda van die toekoms
}

\author{
Lien van Niekerk \& Corinne Meier \\ Dept. Historiese Opvoedkunde \\ Universiteit van Suid-Afrika \\ PRETORIA
}

\begin{abstract}
Apart from social, economic and political forces, there are also religious forces at work which are aimed at changing the character of education in South Africa within the next few years. One of these religious forces which is having an increasing influence on the unrestricted pursuit of Christian education, is the New Age movement. The eclectic world view of the New Age is seen by the uninformed as a postmodernist movement which will ultimately supply the answers to problems in education. For the informed. the New Age symbolises the purposeful replacement of the Christian faith and in addition, the substitution of Christian education with New Age orientated subject matter and teaching methods. The subtle manner in which this infiltration is taking place can only be counteracted by knowledge of and a preparedness against the New Age.
\end{abstract}

\section{Inleiding}

Benewens die sosiale, ekonomiese en politieke kragte, is daar ook religieuse kragte aan die werk wat daarop gerig is om die aard van die onderwys in SuidAfrika oor die volgende paar jaar te verander. Een van die religieuse kragte wat die vrye beoefening van Christelike onderwys toenemend beïnvloed, is die $\mathrm{New}$ Age-beweging. Ingeligte ouers, onderwysers en opvoedkundiges is bewus van die subtiele wyses waarop die New Age-beweging in die Suid-Afrikaanse onderwysmilieu ingang vind. Oningeligte ouers, onderwysers en opvoedkundiges is egter nie daarop bedag nie; waarskynlik omdat relatief min voorvalle van onderwyspraktyke wat direk aan die New Age toegeskryf kan word, in Suid-Afrika opgeteken is. Ander vorme van okkultiese bedrywighede, soos Satanisme, is vir hulle ' $n$ groter werklikheid weens die mediadekking wat dit geniet. Hierdie toedrag van sake bring vrae soos die volgende op die voorgrond: Tot watter mate is New Age-leerinhoude in die onderwyskurrikula opgeneem? Hoe en waar het hierdie verskynsel sy inslag in Suid-Afrikaanse skole verkry? Is dit 'n eietydse verskynsel? Behoort dit as 'n uitlewing van godsdiensvryheid erken te word? 
Die invloed van die New Age-bew'eging op die ondenwysagenda van die toekoms

Die onderhawige artikel het ten doel die inskerping van 'n groter bewustheid oor die aard en die invloed van die New Age-beweging op die huidige onderwysagenda en ook dié van die postmodeme tyd

\section{Wat is die New Age-beweging?}

Die begrip New Age-beweging verteenwoordig die skynwêreld van 'n alternatiewe lewens- en wêreldbeskouing en is nie slegs die Engelse vertaling vir 'n nuwe tydperk nie. Volgens Steyn (s.j.:1) omsluit die beweging 'n wye spektrum gelowe waarvan sommige selfs Christelik voorkom. In hoofsaak is die New Agefilosofie die samevoeging van drie vertikale strominge:

- die alternatiewe religieuse tradisies van die Weste (waarvan okkultiese bedrywighede ' $n$ deel vorm),

- Oosterse filosofieë,

- $\quad$ en die sogenaamde menslike-potensiaalbeweging met sy oorsprong in die humanistiese en transpersonale sielkunde.

Vir die doel van hierdie artikel word geen onderskeid gemaak tussen die onderskeie strominge nie omdat al drie strominge in die onderwys aangetref word.

Die eklektiese lewens- en wêreldbeskouing van die New Age word deur 'n wye sfeer van belangegroepe gehuldig. Martin (1989:136) omskryf die New Age en sy aanhangers soos volg:
A loose organization of people, many of them 'Yuppies', who believe the world has entered the Aquarian Age when peace on earth and one-world government will rule. They see themselves as advanced in consciousness, rejecting Judeo-Christian values and Bible in favor of Oriental philosophies and religion. Among them may be found environmentalists, nuclear-freeze proponents, Marxist-socialist utopians, mind-control advocates, ESP cul- tists, spiritists, witchcraft practitioners, and others using magical rites.

Die saambindende faktor binne dié gedagterigtings is die visie van 'n nuwe tydvak waarin die mens 'n ingrypende geestelike verandering sal ondergaan. Die $\mathrm{New}$ Ager (synde die persoon wat die New Age-leerstellings onderskryf) glo dat die polariserende tydvak van die Christendom (met sy teenpole van goed en kwaad, lig en duisternis) tot ' $n$ einde gekom het en in die huidige tydsgewrig verplaas word met 'n tydvak waar alle teenstellings gaan verdwyn. Astroloë, wat min wetenskaplike aansien het, het reeds hierdie tydvak aangekondig.

Die New Age, wat ook as die Age of Aquarius bekend staan, vind sy oorsprong in die astrologie. Aquarius is die elfde teken in die sodiak (diereriem). Die sodiak is 'n denkbeeldige gordel van twaalf sterregroepe wat voorkom in die baan wat 
die son, maan en planete volg. Benewens die jaarlikse siklus deur die twaalf sterrebeelde, volg die son ook 'n 24,000 jaar lange baan wat in twaalf ooreenstemmende bedelings van 2,000 jaar onderverdeel kan word (De la Guerre, 1991: 35). Die aarde se sonnestelsel beweeg in 'n omgekeerde volgorde deur hierdie sterrebeelde. Die tydperk waartydens die sonnestelsel onder 'n bepaalde sterrebeeld val, word 'n tydvak/era genoem. Met Christus se geboorte is die tydvak van die Visse (pisces) ingelui, wat nou, na bykans 2,000 jaar, deur die tydvak van die Waterdraer (Age of Aquarius) verplaas word (Buitendag \& Van der Merwe, 1991:17).

Astroloë beweer dat die sterrebeelde in hulle konstellasies bepaalde simbole uitbeeld wat ' $n$ invloed op die aarde en sy bewoners uitoefen (Buitendag \& Van der Merwe, 1991:16). Terwyl die son in die nuwe konstellasie inbeweeg, word 'n nuwe en ander energiestroom vrygestel wat die planete se atmosfeer binnedring. Hierdie energie verander nie alleen die fisiese wêreld van die mens nie, maar ook sy geestelike bestaan. Deur die Age of Aquarius word die mens bewus van die innerlike krag en goddelike vermoëns waardeur sy persoonlike lewe asook dié van ander verryk kan word. Waar die tydvak van die Visse geken was aan die rede, rasionaliteit, analise, manlikheid, kragdadigheid en polarisasie word die nuwe tydvak geken aan intuïsie, emosionaliteit, sintese, vroulikheid, liefde en harmonie. Alhoewel die New Age- se lewens- en wêreldbeskouing nêrens eksplisiet uiteengesit word nie, is bepaalde leerstellings geformuleer ter konkretisering van die bovermelde eienskappe van die nuwe tydvak.

\section{Die New Age-leerstellings}

Die volgende is die basiese leerstellings van die New Age (McLoud, 1990:11):

* Monisme en holisme/Alles is een: Alles wat bestaan, maak deel uit van een kosmiese geheel. Die werklikheid is onbegrens. Tussen God, die mens en die natuur is daar geen verskil nie. Ook goed en kwaad word uiteindelik op 'n paradoksale wyse met mekaar versoen. Absolute norme en waardes bestaan nie (Groothuis, 1988:18).

* Panteisme/Alles is god: Alles wat bestaan, is een en daardie een is God. Hindoeisme is die wesenlike godsbegrip van die New Age: daarvolgens is God nie 'n persoon nie, maar 'n onpersoonlike energie, krag of bewussyn wat Brahman genoem word (Groothuis, 1988:10).

* Antropoteïsme/Die mens is god: As alles God is, is die mens ook God. Die mens moet aan die hand van verskillende tegnieke geleer word om die godheid in homself te ontdek (Roszak, 1977:225). 
Die invloed van die New Age-beweging op die onderwysagenda van die toekoms

In 1989 het die Shekum Foundation 'n kennisgewing versprei waarin hulle die volgende sê:

We are all invited to share in the experience of being Christ. We are all being called to a higher dream, a higher purpose wherein we can contact our archetypal self and outpicture that reality in the world .. We are all incamations of Christ.

* Reïnkarnasie Die mens se bestaan is die somtotaal van sy vorige lewens: Omdat alles een is, en alles God is en die mens God is, kan die mens, sodra sy fisiese liggaam sterf, in verskillende 'liggame' voortbestaan totdat die siel volmaak is. Die mens se karma, 'n Indies-godsdienstige begrip wat werk volgens die beginsel dat die mens maai wat hy saai, bepaal die graad van geestelikheid van sy volgende reïnkarnasie (Dreckmeyr, 1991:5). Die mens wat kwaad gedoen het ('n slegte karma het) sal in die volgende lewe slegter daaraan toe wees en omgekeerd.

* Sinkretisme/Alle godsdienste is in wese gelyk: Alle godsdienste verkondig dieselfde waarhede. Verskille is bloot kunsmatig (Groothuis, 1988:22)

* Elke mens skep sy eie werklikheid

'n Analise van die doelstellings, leerinhoude en metodes van die New Age-onderwysteorie en -praktyk stel die wyse waarop die New Age-leerstellings in die onderwys ingedra word, op die voorgrond.

\section{Die New Age-agenda vir hoofstroomonderwys}

Vir die oningeligte versinnebeeld die New Age-filosofie die enigste weg om leerprobleme en ander dringende onderwysvraagstukke te hanteer. Wanneer die onderliggende filosofie en onderwysdoelstellings van die New Age-beweging egter in groter diepte ondersoek word, is daar min waarmee die Christenonderwyser hom uiteindelik kan vereenselwig.

\subsection{Onderwysdoelstellings van die New Age}

Die New Age beskou die onderwys as die transformator waardeur die ou mens (wat behoort tot die tydvak van die Visse) afgelê moet word ter wille van die nuwe mens (wat behoort tot die tydvak van die Waterdraer). Waar dit nie moontlik is om New Age-skole op te rig nie, is die volgende onderwysdoelstellings geformuleer wat daarop gerig is om die New Age-denke in bestaande skole in te voer:

* Die eerste onderwysdoelstelling is reeds in 1805 gestel, en het betrekking gehad op die subtiele en verskanste teëwerking van alle Christelike invloede 
in skole. 'n Stelsel van staatskole sou geïmplementeer word wat ouers wetlik sou verplig om hul kinders daarheen te stuur. In die staatskole moes alle godsdiensbeoefening uit die kurrikula weggelaat word. Alle kennis sou op die vlak van die sintuiglike waarneming en eenwording gebaseer word (Blumenfeld, 1981:95). In verskeie wêrelddele is hierdie doelstelling grootliks vervul.

* Die tweede onderwysdoelstelling is daarop gerig om die kind met behulp van psigoterapeutiese tegnieke in sy diepste wese (bewussyn, denkpatrone en ingesteldheid) te verander of te transformeer. Michaelsen (1989:23) beskryf die werking van hierdie tegnieke in haar boek, Like Lambs to the Slaughter, soos volg:

As applied in the classroom, these techniques are specifically designed to gain access to the inner workings of the child in order to release him from the 'outmoded' values and beliefs of his parents and to 'improve' him with the 'new' and 'desirable' Humanist beliefs appropriate to the 'global citizen' they expect him to become.

Om uitvoering te gee aan hierdie doelstelling, agiteer verskeie onderwysbeleidmakers in die VSA vir verpligte onderwys vanaf die ouderdom van drie jaar! Dit sal die New Age-onderwyser in staat stel om die kind die 'regte' vorming te gee "before the parents have a chance to infect him with their middle-class diseased beliefs in God, morality, and allegiance to this country" (Michaeisen, 1989:28).

* Die derde doelstelling is daarop gerig om die onderwys te 'suiwer' van onderwysers wat Christelike norme en waardes aanhang (Endres, 1991:11). Indiensopleidingseminare is een van die wyses waarop hierdie 'suiwering' moet geskied. Onderwysers wat nie die New Age-leerstellings en doelstellings onderskryf of hulle met die aard van die seminare vereenselwig nie, word mettertyd uitgefaseer.

Die oorkoepelende doel van die New Age is dus om die onderwys so te transformeer dat die transformasie van die kind die logiese gevolg is. Ferguson (1980: 93) beskryf die vier fases van transformasie wat beoog word soos volg:

* Die intreevlak, of eerste fase is gerig op die verdagmaking van ou en bestaande waardesisteme en prioriteite.

* Die tweede fase of eksplorasiefase, is daarop gerig om die twyfel en onsekerheid wat by die kind ontstaan het oor die 'weg' en die 'waarheid' so te voed dat hy self begin antwoorde soek by die nog onbekende werklikheid waar die antwoorde waarskynlik te vinde is. 
* In die derde fase, die integrasiefase, word die kind geleer om sy steun te vind by ' $n$ innerlike gids of beskermer op wie hy te alle tye kan staatmaak.

* Tydens die vierde en die finale fase, of die fase van eedgenoodskap, ontdek die kind ander bronne van krag buite homself. Hy word ook geleer hoe om hierdie magte en kragte tot sy eie voordeel en in diens van ander aan te wend. Rose (1979:115) omskryf die guru of innerlike gids waarna Furguson in hierdie fase verwys as 'n "personal guide, protector, or talisman".

Indien kinders in die hoofstroomonderwys die teikengroep vir New Age-transformasie is, is begaafde kinders dit soveel te meer. Uit die geledere van begaafde kinders kom die leiers, regslui, medici, politici en onderwysers van die toekoms. Dit is ook die begaafde kind aan wie die verwagting gestel word om die $\mathrm{New}$ Age-leier van die toekoms te word "and as such they must receive special attention and indoctrination from the social engineers" (Michaelsen, 1989:49). Begaafde kinders moet meer intensief aan New Age-leerinhoude en onderwysmetodes blootgestel word. Alhoewel die New Age-onderwyspraktyke in hoofstroom- en begaafdekindonderwys bloot gradueel van mekaar verskil, is dit belangrik om daarvan kennis te neem.

In 'n artikel in die gesaghebbende tydskrif Gifted Children Monthly, skryf die wêreldkenner op die gebied van begaafdekindonderwys, Dorothy Sisk, oor die doelstellings wat die New Age-beweging met begaafdekindonderwys het. New Age-onderwysers moet fokus op leerlinge met besondere leierseienskappe en eienskappe soos die vermoë tot probleemoplossing, kommunikasievaardighede, 'n positiewe selfkonsep en 'n hoë vlak van gemotiveerdheid. Met hierdie doelstellings kan geen fout gevind word nie, maar dan sluit sy haar artikel af met die opskrif "Training the Third Eye". Sisk verduidelik hoe hierdie opleiding moet geskied en moedig onderwysers aan om die begaafde kind te leer "to listen to the small voice within our intuitive selves" (Sisk, soos aangehaal in Michaelsen, 1989:50). Ouers en opvoeders wat nalaat om die begaafde kind te onderrig in die antieke Oosterse mistiese tegnieke, waardeur die derde oog geopen moet word, is volgens Sisk nie in staat om 'n atmosfeer van warmte en aanvaarding te skep of die kind se waardes en kreatiewe vermoëns te erken nie.

Alhoewel die onderwysdoelstellings van die New Age-beweging in Suid-Afrika veel minder eksplisiet aantoonbaar is, beteken dit nie dat die beweging nie ook aktief besig is om na vastrapplek in die onderwys te soek nie. Deur kennis te neem van die manifestasie daarvan elders in die wêreld, is dit makliker om ouers en opvoeders te oortuig van die werklikheid daarvan.

Vir die New Age om neerslag te vind in die onderwys, is die klaskamer die natuurlike vertrekpunt. 


\subsection{Die New Age in die klaskamer}

Die New Age wil nie oornag 'n nuwe wêreldorde tot stand bring nie: dit moet 'n geleidelike proses wees met die onderwys as konsentrasiepunt. Onderwysers is die veranderingsagente wat die kind moet transformeer om die New Age-leerstellings aan te hang. Sielkundiges word ook as belangrik uitgesonder omdat hulle menings en aanbevelings dikwels onvoorwaardelik en onkrities deur onderwysers en ouers aanvaar word. Die belangrikheid van die onderwys vir die New Age lê opgesluit in die volgende woorde van Brooks (1981/82:4):

... it influences the most people in the most pervasive way at the most impressionable age. No other social institution has anything close to the same potential for mass indoctrination.

Hierdie uitgangspunt verklaar waarom daar meer New Agers in die onderwys is as in enige ander beroepsveld (Ferguson, 1980:280). Die New Age se betrokkenheidsvlak bestryk die breë onderwysterrein: onderwysers, administrateurs, beleidmakers en opvoedkundige sielkundiges.

\subsubsection{Die New Age-onderwyser}

In die VSA word groot gewag gemaak van die opleiding van onderwysers in die New Age-filosofie. Net soos wat die onderwys op die transformasie van die kind afgestem is, is onderwysersopleiding gerig op "personal transformation" (Ferguson, 1980:281), wat letterlik oormaak, herkonstruering of transformasie van die diepste wese van die onderwyser beteken. Die onderwyser wie se denke getransformeer is, word 'n New Age-agent wie se taak dit is om die bestaande wêreldorde te verander. Onderwysers wat weier om hulle aan persoonlike transformasie te onderwerp, word mettertyd met New Age-onderwysers vervang. Die gevolg is dat tienduisende onderwysers, onderwyskundiges, opvoedkundiges, skoolvoorligters, administrateurs, navorsers en akademici deel uitmaak van die miljoene mense wat regoor die wêreld by persoonlike transformasie betrokke is (Ferguson, 1980:281).

Die kurrikulum vir onderwysersopleiding sluit onder meer die volgende inhoude in:

... how to lead the children on guided imagery/visualization trips, how to build a 'psychic room', how to contact their spirit guides, how to read auras, and how to conduct out-of-body experiences (Michaelsen, 1989:34)

Die New Age-onderwyser word ook opgelei om van 'onskadelike' eufemismes gebruik te maak om ouers te mislei oor die wesenlike aard van die leerinhoude wat onderrig word. Okkulte onderwyspraktyke word verbloem met aangepaste begrippe soos sentrering (meditasie), bewustheidsopleiding en holistiese leer- 
metodes. Min New Age-onderwysers is bereid om te erken dat hulle met sodanige praktyke in die onderwys besig is.

\subsubsection{New Age-handboeke}

In 'n ondersoek wat Vitz (1985:1) in 1985 in die VSA gedoen het, het hy bevind dat die tradisionele konsep van moraliteit, die gesin, nasionalisme en die Christelike godsdiens op alle jaarvlakke, in handboeke weggelaat word. Die weglating daarvan laat by kinders die idee dat dit onbelangrik is en geen waarde het nie. Moberly (soos aangehaal in Groothuis 1988:131) rig die volgende waarskuwing in hierdie verband:

It is a fallacy to suppose that by omitting a subject, you teach nothing about it. On the contrary you teach that it is to be omitted, and that it is therefore a matter of secondary importance. And you teach this not openly and explicitly, which would invite criticism; you simply take it for granted and thereby insinuate it silently, insidiously, and all but irresistibly.

In New Age-handboeke is Christelik gebaseerde leerinhoude vervang met verwysings na Indiese en ander paganistiese (nie-Christelike) godsdienste. Wanneer in ag geneem word dat ongeveer $75 \%$ van die klaskamertyd en $90 \%$ van 'n leerling se tuiswerktyd met die bestudering van handboekinhoude opgeneem word, is 'n berekening van die invloed van New Age-leerinhoude voor die hand liggend (Gabler \& Gabler, 1985:22)

\subsubsection{Waardeverheldering}

Die begrip waardeverheldering is op sigself instruktief en selfbegeleidend. Die woord waarde, eerder as etiek of moraal, dra die betekenis dat reg en verkeerd en goed en kwaad iets is waaroor die mens self besluit.

Waardeverhelderingsprogramme is op die volgende gerig:

* Die New Age-onderwyser moet die 'waarheid' aan die kind verkondig. Die volgende geld as die 'waarheid': dat kerklike en gesinswaardes en morele oortuigings oudmodies en uitgedien is en dat ouers en die kerk nie langer die reg het om sodanige waardes aan die kind op te dring nie. Die waarheid impliseer dat enige waarde of morele oortuiging vir die kind as die korrekte kan en moet geld, hetsy dit op homoseksualiteit, aborsie, dwelmmisbruik of voorhuwelikse seks betrekking het. Die klem val hier op die vrye keuse waartoe die kind 'n reg het (Michaelsen, 1989:19). Volgens die New Agedenke is die onderwyser nie meer die gesagsdraer nie en moet die gedagtes, gevoelens en idees van die kind sonder vooroordeel of kritiek aanvaar word. Waardeverheldering is nie daarop gerig om die objektiewe, universele en absolute waardesisteem van die Christen te ontdek nie. Die kind moet leer 
om inklusief (monisties) te dink want die mens self is die maatstaf van alle dinge.

* Dit is met ander woorde die taak van die New Age-onderwyser om die kind te lei om ' $n$ subjektiewe waardesisteem te ontwikkel. Deur middel van praktiese oefensessies moet die kind bewus gemaak word van sy eie gevoel, sy eie idees, sy eie siening sodat die keuses en besluite wat hy neem, gebaseer is op sy eie waardes (Baer, 1989:113-115).

* Die New Age-onderwyser moet die kind ook bewus maak van die relatiwiteit van die werklikheid. 'n Eie leefwêreld en realiteit moet geskep word waar liggaam en siel verenig en die breinvermoë optimaal benut word. Clark (1983:397-398) beskryf die aard van hierdie realiteit soos volg:

Lifestyles and belief systems change, dichotomies no longer exist, and time and space have another dimension. Reality is seen as an outward projection of internal thoughts, feelings, and expectations. Energy is the connector, the center, the basis of all matter, and consciousness forms reality.

Waardeverhelderingsprogramme kondisioneer die kind om bewus te word van die goddelike vermoëns waaroor hy beskik en leer hom om homself tot god te verhef.

\subsubsection{Confluent education}

Op sigwaarde wil dit voorkom asof confluent education geensins van die tradisionele onderwyspraktyke verskil nie. In albei gevalle word die kognitiewe én die affektiewe domein aangespreek: daarvolgens kan leer nie van gevoel geskei word nie, en andersom. Vrae soos die volgende word algemeen gevra:

- Hoe voel die kind oor die leerinhoude wat onderrig word?

- Sluit die leerinhoude aan by die leefwêreld van die kind?

Die verskil tussen die Christelike en die New Age-onderwyspraktyke lê in die wyse waarop hierdie vrae beantwoord word. Die Christenonderwyser selekteer leerinhoude wat gerig is op die vorming van die kind vir die hiernoumaals (behoorlike genormeerde volwassenheid) en die hiernamaals (die ewige lewe). Die New Age-onderwyser selekteer leerinhoude wat die persoonlike behoeftes en gevoel van die kind hier en nou aanspreek. Hierdie leerinhoude dien as hulpmiddel om die kind bewus te maak van sy eie goddelikheid want God is in alles en in almal; daarom is elke mens ook deel van die godheid en tot alles in staat (Ankerberg \& Weldon, 1991:268). Creme (1980:68) skryf:

We must show our ability to become One with All, the Whole of this planetary life ... show that this is One World, One humanity, One life. 
Om hierdie staat van "One with all" te bereik, word confluent education aan die hand van geleide verbeelding onderrig en vind dit gestalte tydens transpersonale onderwys.

\subsubsection{Transpersonale onderwys}

New Agers verwys ook na transpersonale onderwys as geïntegreerde, holistiese of bewussynsonderwys. Alhoewel 'n onderwysbegrip soos die integrasie van leerstof en vermoëns nie 'n New Age-term per se veronderstel nie, het die begrip integrasie in die New Age-onderwyspraktyk 'n eufemisme geword vir die begrip transpersonale onderwys.

Die doel met transpersonale onderwys

... is to present ancient occult techniques to students in order to open them up to the experience of 'self-transcendence'... It is the experience of 'enlightenment' of Eastern mysticism, the ecstatic experience of unity of blinding light, the realization that All is One, One is All, therefore everything is God, including you! (Michaelsen, 1989:40).

Hierdie opportunistiese siening word ook deur Alice Bailey, hoëpriesteres van die New Age-beweging, gehuldig. Sy het in 1947 'n boek gepubliseer met die titel, Education in the New Age, waarin enlightenment as die hoofdoel van die onderwys geproklameer word. Sy wys voorts daarop dat die boek in sy geheel 'n bloudruk en 'n wekroep vir okkultiese transformasie van onderwysers en opvoedkundige inrigtings is (Michaelsen, 1989:41).

Voorstanders van transpersonale onderwys deel die siening dat die kind 'n innerlike geestelike gids moet hê:

Transpersonal educators view this guide as extremely helpful in contacting one's 'Higher Self' or 'Inner Wisdom', that part of yourself which mystics say is God. In addition to which, as most well-grounded occultists know, you don't want to get caught in your meditational metaphysical ozone without at least one guide (Michaelsen, 1989:87).

Transpersonale onderwys en okkultiese leerinhoude word in die klaskamer toegelaat onder die dekmantel dat dit op die ontwikkeling van die kind se selfbeeld gerig is.

Ook in programme vir begaafdekindonderwys geniet transpersonale onderwys toenemende aandag:

This is in fact the perfect setting for Transpersonal education, because the programs by their very nature are so open to experimentation (Michaelsen, 1989:51). 
In haar werk, Growing up Gified, bevestig Barbara Clark (1983:398), 'n vooraanstaande geleerde op die terrein van begaafdekindonderwys, dat die onderrigmetodes van die ou Chinese, Hindoes en Egiptenare van besondere belang in transpersonale onderwysprogramme is. Al wat die New Age-onderwyser moet doen, is om seker te maak dat die begaafde kind in transpersonale onderwys belangstel.

\subsubsection{Visualisering en geleide verbeelding}

Visualisering en geleide verbeelding, wat sy oorsprong in Babilonië, Assirië, Sumerië en Griekeland het, is 'n oeroue praktyk en 'n integrale deel van okkultiese godsdienste (Samuels \& Samuels, 1975:21). Genoemde outeurs omskryf visualisering en geleide verbeelding as ' $\mathrm{n}$ "form of concentration on an image" (Samuels \& Samuels, 1975:21). Die New Age-onderwyser leer die kind om met toe oë te ontspan en sy verbeelding vrye teuels te gee. In sommige gevalle skep die onderwyser vir die kind die beeld van 'n droomland waar alles waar kan word. In hierdie droomland, wat te alle tye toeganklik is, is die kind 'n volmakte wese, al swewende en vol lig. In ander gevalle skep die kind self sy droomwêreld (Martin, 1989:61). Hierdie droomwêreld bly nie net by denkbeelde nie. Deur middel van visualisering word die kind gehelp om sy droomwêreld in 'n werklikheid te omskep: Wat jy dink is wat jy ontvang. Hierdie inbeelding geskied aan die hand van joga en meditasie.

\subsubsection{Joga en meditasie}

Joga is deel van die Hindoeïstiese godsdiensbelewing. Verskeie soorte joga word onderskei: Hatha joga (liggaamsoefeninge), Kundalini joga (wat beloftes van fisiese en geestelike genesing inhou) en Tantra joga (wat ook op die mediese gebied aangewend word) (De la Guerre, 1991:110). Die Hindoes gebruik ook Karma, Bhakti, Jnana en Raja joga. Alle soorte joga betrek okkultiese veronderstellinge en is op ' $n$ eenheid met Brahman, die god van die Hindoes, gerig

Joga word dikwels as deel van asemhalingsoefeninge en liggaamlike fiksheid in skole beoefen. ' $n$ Kind wat joga beoefen, se gedagtes word totaal geneutraliseer, die liggaam word passief en alle bewussyn van die fisiese wêreld word afgesny. Kock (1983:257) beskryf die atmosfeer waarin joga beoefen word soos volg:

* Die hoër ego van die mens is transendent en immanent: sonder ' $n$ begin of ' $n$ einde, sonder 'n geboorte en 'n sterfte.

* Joga beteken die sintese van die fisiese en die metafisiese wêreld.

* Die hemel en die hel is slegs produkte van die mens se gemoed.

Meditasie vorm ' $n$ belangrike deel van joga. Die doel van meditasie is om: 
* die ou slegte karma wat in die onderbewuste is, te elimineer of uit te skakel en die gedagtes te reinig,

* 'n superbewussyn te kweek en te ontdek dat die mens self god is en sy eie lewe bepaal (De la Guerre, 1991:124)

Die New Age verskaf die volgende riglyne aan die hand waarvan onderwysers die beoefening van meditasie behoort te rig.

* Meditasie vir gedagtebeheer

Die hoofdoel van joga is om die jogi (die persoon wat joga beoefen) te voer tot 'n gedagtestilstand, dit wil sê die uitwissing van alle kennis en kenbare dinge. 'n Eie leefwêreld en 'n eie werklikheid moet deur middel van meditasie geskep word. In hierdie skynwerklikheid (maja) bestaan probleme soos siekte, armoede, finansiële druk en ander ontwrigtende omstandighede nie. Probleme is ' $n$ illusie wat in die kind se gedagtes reggestel moet word.

* Meditasie vir innerlike beheer

Nadat alle negatiewe gedagtes geneutraliseer is, moet die kind sy gemoed met nuwe gedagtes vul. Innerlike vrede en selfbeheersing word ook deur die Christen nagestreef. Daar is egter ' $n$ groot verskil tussen geestelike bepeinsing en Oosterse meditasie. Die verskil lê veral daarin dat die New Agegodsdiens rondom die self sentreer en dat die kind poog om sonder God beheer oor sy lewe te verkry (Baer, 1989:61). Hierdie gedagtes moet ook uitgestraal word na die ander in die klaskamer.

\section{* Transendentale meditasie}

Transendentale meditasie verwys na 'n ervaring buite die liggaam of soos Kock (1983:247) dit stel: "transcendental means no more than crossing from conscious to unconscious activity". Voorstanders van transendentale meditasie roem daarop dat dié tegniek deur enige godsdiens beoefen kan word. Hierdie aanname het daartoe gelei dat regerings, wat verskeie godsdienstige groepe verteenwoordig, en selfs Christelike kerke, die standpunte van die voorstaanders van transendentale meditasie aanvaar. Transendentale meditasie is daarop gerig om

- die hoogste doel met opvoeding te bereik,

- die volle potensiaal van die kind te ontwikkel,

- die geestelike doelwitte van die mensdom in die algemeen te bereik,

- probleme soos misdaad en dwelmmisbruik op te los, 
- die optimale intelligente gebruik van die natuur te verseker,

- dit wat deur die regering bereik is, te verbeter.

Die afkeurenswaardige van transendentale meditasie lê nie in die sake wat betrek word nie, maar in die wyse waarop dit gedoen word. Die onderwyser skep by die kind die illusie dat die beoefening van transendentale meditasie hom met 'n bepaalde almag toerus. Op hierdie wyse word die kind stelselmatig ingelei in die heidense Oosterse godsdiensfilosofie (De la Guerre, 1991:131). Transendentale meditasie lei verder tot:

- misleidende selfhipnose,

- eenvoudige self-vergoddeliking,

- natuurlike godsdiens wat die mens nie kan red nie,

- demoniese misleiding (Bjornstad, 1976:46).

In aansluiting daarby, rig Groothuis (1988:68) die volgende waarskuwing:

Even advocates of yoga report the dangers of the energy (kundalini) it may awaken. This may involve insanity, physical burning, sexual aberrations, and so on.

Die New Age infilteer nie net bestaande skole nie. New Age-skole word ook toenemend gestig.

\section{New Age-skole}

Die twee belangrikste New Age-skole wat ook in Suid-Afrika toenemend op die voorgrond tree, is die sogenaamde Montessori-en Waldorfskole.

\subsection{Montessoriskole}

Maria Montessori (1870-1952) was 'n aanhanger van die Teosofie wat die basis van die New Age-filosofie is. Die Teosofie is 'n mistieke denkrigting, gestig deur Helena Blavatsky (1831-1891) met die doel om 'n universele broederskap tot stand te bring, psigiese verskynsels te ondersoek en vergelykende studies van wêreldgodsdienste uit te voer (Gardiner, 1991:117)

Maria Montessori het in die twintiger- en dertigerjare ten nouste met die fascistiese leier Benito Mussolini (1883-1945), Adolf Hitler (1889-1945) van Duitsland en Mahatma Ghandi (1869-1948) van Indië saamgewerk om die New Ageleerstellings in die praktyk deur te voer. Vandag word die Montessorimetode by die New Age-kommune van Elizabeth Clare Prophet, hoof van die kultiese Church Universal and Triumphant, onderrig. Die amptelike leerplanne bestaan 
uit die aanbidding van die natuur en die Moedergodin, Aarde; okkulte simbole; New Age-fantasieverhale van Atlantis en Lemuria; Hindoefilosofie; die NaziAriese superras-teorie; Egiptiese mitologie en die universele eenheid-tema (Gardiner, 1991:72). Die Montessorileerplanne is daarop gerig om die kind te help om sy eie plek in die kosmos te vind. Hierdie eie plek sluit in inkarnasie (die New Age se teenvoeter vir gebed) en humanisering deur die mikrokultuur. Onderwysers het as taak om die kind te help om die mikrokultuur te transendeer en die wêreldkultuur te inkarneer.

In Suid-Afrika is daar vandag talryke kleuterskole wat sekere beginsels van die Montessorimetode oorgeneem het. Die belangrikste operasionele beginsel van die Montessorimetode beklemtoon die aangebore goedheid van die kind, die spontane aard van ontwikkeling en die belangrikheid om onderwyspraktyke op die kind se natuurlike belangstellings te fikseer (Garbers et al., 1976:164).

Die Montessorimetode berus op ' $n$ geloof in die vryheid van die gees van die kind en hierdie vryheid word ten beste ontwikkel in 'n omgewing wat rondom sensoriese ervaring georganiseer word. Die toepassing van hierdie metode impliseer nie dat die New Age-godsdiensfilosofie noodwendig onderskryf word nie. Dit dien eerder as waarskuwing dat die onderliggende filosofie van enige metode vooraf ondersoek behoort te word.

\subsection{Waldorfskole}

Rudolf Steiner, voormalige hoof van die Duitse afdeling van die teosofiese vereniging, is die stigter van die Waldorfskole. Waldorfskole is wêreldwyd, ook in Suid-Afrika, opgerig met die doel om 'n geestelike bewustheid by die kind te wek. Die kind ontvang onderrig in mistiese tradisies en sake soos reïnkarnasie, karma, chakras (sewe energiepunte wat van die onderpunt van die ruggraat tot bo-op die kop loop, elk met 'n eie kleur en vibrasietempo) en meditasie (Gardiner, 1991:114 \& 116). Die Waldorfskole onderskryf die New Age-filosofie en die New Age-doelstellings.

\section{Gevolgtrekking}

Die Christelike geloof gaan van die standpunt uit dat die sin van die opvoeding sy oorsprong in God het (Dooyeweerd in Van der Walt, 1992:92) en dat die opvoedingsverskynsel deur God daargestel is om sy Raadsplan te verwesenlik. Indien daar dan 'n ontkenning van God as singewer is, word die opvoeding aan sekularisme en humanisme uitgelewer (Van der Walt, 1992:92-93). Die New Age-beweging ontken God as singewer en gaan selfs so ver om die Christelike godsdiens te misken en teë te werk (Blumenfeld, 1981:95). Die negering van God as singewer behoort alreeds as waarskuwing te dien. Tog word die New Age 
in talryke voorlesings en teekamerbesprekings opgehemel as 'n postmodernistiese beweging wat uiteindelik die antwoord op onderwysprobleme kan bied. Voorstanders van die $\mathrm{New}$ Age-beweging reageer meestal met verontwaardiging op enige kritiek wat die inwerking daarvan op die onderwys veroordeel. Verontwaardiging maak egter nie die geesteskade wat dit die kind aanrig, ongedaan nie. Die onderwys kan ook nie onder kwarantyn geplaas word in die hoop dat die probleem sal verdwyn nie. Die probleem moet behandel word.

Die inskerping van 'n groter bewustheid by opvoeders oor die aard en invloed van die New Age-beweging op die onderwysagenda van die betrokke tydsgewrig, behoort as prioriteit te geld by onderwysinrigtings wat met die beroeps- en indiensopleiding van onderwysers gemoeid is. Onderwys is steeds 'n lewensopvatlike aangeleentheid waarin die een of ander lewens- en wêreldbeskouing meespreek. Vir die Christenopvoeder geld Exodus 20:2-3: "Ek is die Here jou God ... jy mag naas My geen ander gode hê nie" (Bybel, 1985:89). Hierdie Bybelsgefundeerde uitgangspunt laat geen ruimte vir die New Age-doelstellings van monisme, holisme, panteïsme, antropoteïsme, reïnkarnasie en sinkretisme nie (McLoud, 1990: 11).

'n Geleentheid tot inskerping doen hom tans voor met die snel veranderende onderwysstelsel in Suid-Afrika. 'n Groot aantal skole het sedert 1 Augustus 1992 na Model-C oorgeskakel. Daardeur is die bevoegdheid om die gemeenskapskarakter in skoolverband te verreken, na bestuursliggame gedelegeer. Nuutaangestelde bestuursliggame het as eerste opgaaf die opstel van 'n grondwet waarin ook die etos en missie van die skool uiteengesit word. Dié keuse skep die moontlikheid dat ' $\mathrm{n}$ ander etos as 'n Christelike etos in die toekoms voorgestaan kan word. Hierdie moontlikheid dwing bestuursliggame en onderwysers om opnuut te besin oor die aard en wese van eksterne invloede wat die karakter van die skool sodanig kan beïnvloed dat dit die lewe en die toekoms van die kind kan verander en selfs kan vernietig.

Opvoedkundiges wat met onderwysersopleiding besig is, het 'n soortgelyke taak. Dit is ' $n$ foutiewe aanname om te aanvaar dat die karakter en filosofie van die onderwys in Suid-Afrika steeds Christelik is. Kennis omtrent die New Age-filosofie en die onderwysteorie en -praktyk daarvan, is die enigste wyse waarop onderwysstudente en onderwyspraktisyns bewus gemaak kan word van die subtiele wyse waarop die New Age die kader van Christelike onderwys betree. 'n Ingeligte onderwysstudent is uiteindelik 'n weerbare onderwyspraktisyn.

\section{Bibliografie}

ANKERBERG, J. \& WELDON, J. 1991. Cult Watch. Eugene, Oregon : Harvest House Publishers. 
Die invloed van die New Age-beweging op die onderwysagenda van die toekoms

BAER, R.N. 1989. Inside the New Age Nightmare. Lafayette, Louisiana : Huntington House, Inc

BJORNSTAD, J. 1976. The Transcendental Mirage. Minnesota : Dimension Books

BLUMENFELD, SAMUEL L. 1981. Is Public Education Necessary? New York : Old Greenwich

BROOKS, A. 1981/82. The Rise of Cosmic Humanism: What is Religion, SCP Journal:5, Winter.

BUITENDAG, J. \& VAN DER MERWE, P. 1991. Die New Age-beweging. Vereeniging Christelike Uitgewersmaatskappy.

BYBEL. Nuwe vertaling. 1985. Kaapstad Bybelgenootskap van Suid-Afrika

CLARK, B. 1983. Growing up Gifted: Developing the Potential of Children at Home and at School. Ohio : Charles E. Merrill Publishing Co

CREME, BENJAMIN. 1980. The Reappearrance of the Christ and the Masters of Wisdom. London: The Tara Press.

DE LA GUERRE, F. J. 1991. Elke New Age-knie sal buig. Potchefstroom : Wesprint

DRECKMEYR, M. 1991. 'n New Age-blik op die skool en skoolonderwys. Pretoria : Opvoedkundevereniging van Suid-Afrika.

ENDRES, A. 1991. New Age 'n bedreiging. Southdale : Baruk

FERGUSON, MARILYN 1980. The Aquarian Conspiracy. London : Paladin Grafton Books.

GABLER, MEL \& GABLER, NORMA 1985. What Are They Teaching Our Children? Wheaton: Victor.

GARBERS, J.G., FAURE, J.S. \& KOK J.C. 1976. Die ontwerp van opvoedingsprogramme vir kleuters. Stellenbosch : Universiteits-uitgewers en -boekhandelaars (Edms.) Bpk.

GARDINER, J. 1991. Die Nuwe Era-kultus. Kaapstad : Struikhof.

GROOTHUIS, DOUGLAS R. 1988. Confronting the New Age. Illinois : Intervarsity Press

KOCK, K. 1983. Occult A B C. Aglasterhausen : Literature Mission

MARTIN, W. 1989. The New Age Cult. Cape Town : Struik Christian Books.

McLOUD, W.S. 1990. Alles omtrent die "New Age". Die Wilgers : Projek Word Wakker Suid-Afrika.

MICHAELSEN, J. 1989. Like Lambs to the Slaughter. Eugene, Oregon : Harvest House Publishers

ROSE, ROBERT 1979. A Program Model for Altering Children's Consciousness. The Gifted Child Quarterly, 13(1):109-117, Spring.

ROSZAK, T. 1977. Unfinished Animal. New York: Harper and Row

SAMUELS, MIKE \& SAMUELS, NANCY. 1975. Seeing with the Minds Eye: The History, Techniques and Uses of Visualization. New York : Random House.

STEYN, CHRISSIE s.j. Die New Age-beweging. Pretoria : C.B. Powell Bybelsentrum, Universiteit van Suid-Afrika.

VAN DER WALT, J.L. 1992. Fundamentele opvoedkunde en die ontisiteit van opvoeding. Pretoria : RGN Uitgewers.

VITZ, P. 1985. Religion and Traditional Values in Public School Textbooks. Fducation Newsline, December 